\title{
Study on the Assessment of the Oxygen Regime and the Nutrients Content of Some Water Streams in Gorj County
}

\author{
DANIELA CIRTINA ${ }^{1 *}$, MARIA NICOLETA MIHUT ${ }^{2}$ \\ ${ }^{1}$ Constantin Brancusi University of Targu-Jiu, Faculty of Medical and Behavioral Sciences, 4 Tineretului Str., 210185, \\ Targu-Jiu, Gorj, Romania \\ ${ }^{2}$ Constantin Brancusi University of Targu-Jiu, Faculty of Engineering, 30 Eroilor Str., 210135, Targu-Jiu, Gorj, Romania
}

\begin{abstract}
The study aims to characterize the quality of some representative surface waters of Gorj county's hydrographic network by assessing the oxygen regime, namely the dissolved oxygen content (DO), the chemical oxygen demand (COD-Cr), the biochemical consumption of oxygen $\left.\mathrm{BOD}_{5}\right)$ and nutrients measured by ammonium $\left(\mathrm{N}-\mathrm{NH}_{4}{ }^{+}\right)$, nitrites $\left(\mathrm{N}-\mathrm{NO}_{2}{ }^{-}\right)$, nitrates $\left(\mathrm{N}-\mathrm{NO}_{3}{ }^{-}\right)$, total nitrogen,

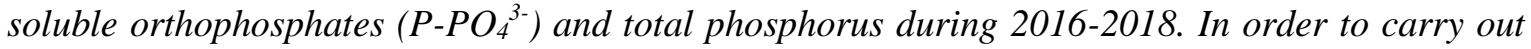
the study, representative sections of the Jiu, Motru and Jilt rivers were monitored in areas considered vulnerable to nutrient and organic pollution. The results regarding water quality from the monitored natural receptors generally showed an evolution within the limits allowed by the environmental legislation, except for the nitrite content that was exceeded for all three monitored rivers. Also, the values of the COD-Cr and $\mathrm{BOD}_{5}$ indicators have been exceeded in some Jiu and Jilt river monitoring sections. Consequently, there is a need to monitor the mentioned parameters.
\end{abstract}

Keywords: water quality indicators, monitoring, nutrients, oxygen regime

Water is a renewable, but limited, natural resource, an important component of natural ecosystems. Human activity exerts a direct influence, subjecting it to a powerful degradation process, with adverse consequences on the environment and human health. The effects of the pollution of water resources are complex and varied, depending on the nature and concentration of the contaminants [1].

Due to the multifunctional and multiple uses of water, the inconsistency between time and space distribution of water resources and requirements, as well as due to the reuse of water, along the watercourses it is necessary to coordinate the management and use of water resources [2]. In practice, the efforts of all the actors involved should focus on the use, development and protection of water resources in a fair and reasonable manner, namely the application of the concept of sustainable development in the field of water management, using the most modern ways offered by current legislation and practice at European level [3, 4].

For the sustainable development of water resources, it is necessary to act for the monitoring of surface and groundwater quality, the knowledge, preservation, rationalization, restoration and exploitation of surface and groundwater resources, protection of water resources and aquatic ecosystems, warning and rapid action to prevent and to eliminate the effects of different types of water pollution [5-7].

One of the fundamental objectives of the sustainable development concept is the assessment of the quality of surface waters in accordance with the legislative norms currently applicable at European level. The ecological status of the rivers is assessed by integrating biological and bacteriological quality indicators with chemical and physicochemical indicators [8-10]. From the chemical point of view, there are several criteria for grouping compounds that define water quality conditions, differentiated by: their nature, the form underlying the aquatic environment, the toxic effect, the properties and the role played in aquatic ecosystems [11-13 ]. Monitoring of water quality is the activity of long-term standardized and long-term observation and measurements for the knowledge and evaluation of the characteristic parameters of the water for management purposes and for the definition of the state and tendency of their quality evolution, as well as the permanent highlighting of the status of the water resources $[14,15]$.

By monitoring water quality, a systematic assessment of the water qualitative characteristics, which is in permanent dynamic and with significant socio-economic implications, is made and it represents a fundamental element in the prevention of water pollution [16]. Starting from a rigorous water quality monitoring and control system, a series of water pollution abatement measures can be developed and implemented, such as: introducing on a large scale non-polluting technologies in industrial processes, reducing the amount of wastewater discharged into rivers through introduction of water recirculation practice, recovery of useful materials from wastewater, thus having the advantage of providing real sources of raw materials, improving purification efficiency by upgrading the technologies, equipments and their exploitation [17-22].

*email:danielacirtina@gmail.com 


\section{Experimental part}

In the present study, the evaluation of the quality of important surface waters for the Gorj county hydrographic network was determined by monitoring the Jiu River and two of its tributaries, namely the Motru and Jilt rivers. During the monitoring (2016-2018), water samples were collected from different sampling sections, settled as representative of water quality. Thus, taking into account the intensity of anthropogenic activities in the areas adjacent to these water courses, their specificity and their vulnerability to nutrients and the loading of organic pollutants, different monitoring sections were delimited and sampling points were established. For these, it has of course started from the inventory of the main sources of pollution of monitored water courses, knowing that for Gorj County a major influence on the quality of surface waters has discharges of unpurified or insufficiently treated wastewater in natural receptors.

Laboratory determinations included physicochemical analyzes to determine the nutrient content and to assess the water oxygen regime of the three natural receptors, Jiu, Motru and Jilt, which are part of the middle hydrographic basin of the Jiu river, on the territory of Gorj County.

Standard sampling methods for surface water were applied using perfectly clean plastic containers (polyethylene) to prevent possible contamination. The harvesting containers were completely filled with water and tightly sealed during immersion to prevent oxidation processes occurring at oxygen-water interface. The samples were transported at a suitable temperature, depending on the indicators to be analyzed, and safely in order to avoid damage or destruction of the container and contamination or loss of the sample [23].

The state of water quality was assessed following the categorization of two categories of quality indicators, this classification being determined on the basis of the weight of each element of physical-chemical quality determined by comparison with the limit values provided by the legislation in force. Thus, there were determined oxygen category indicators such as: dissolved oxygen, chemical oxygen demand, five-day biochemical oxygen demand, and nutrients, including: ammonium, nitrates, nitrates, total nitrogen, total orthophosphates and total phosphorus. When setting the indicators, we considered the nature of the pollutants that have been dischargend into natural emissaries as a result of anthropogenic activities influencing water quality, aiming to verify the degree of loading with organic pollutants with negative effects on the ecosystem. It has also been tracked which of the determined values are approaching or exceeding the maximum admissible values for the analyzed water category.

The methods of analysis applied were the standardized ones: the ammonium, nitrate, nitrite, total nitrogen, total orthophosphate and total phosphorus contents were determined by spectrophotometric analysis using a Cintra 101 UV-VIS spectrometer. Oxygen regime indicators: dissolved oxygen, chemical oxygen demand and biochemical oxygen demand were determined by volumetric analysis methods and standardized electrochemical methods using a Consort multiparameter.

\section{Results and discussions}

According to the recorded values, each physico-chemical indicator analyzed was classified in the corresponding quality class by comparing the average value with the admissible limit value according to the "Normative regarding the classification of surface water quality in order to determine the ecological status of the bodies of water" no. $161 / 2006$ [24]. We specify that the measurements were made over several months, but the annual averages were established on the basis of which were plotted the corresponding evolution of each indicator during the monitoring period.

In order to obtain a complete characterization of the water quality, sampling was carried out from different sections of the monitored courses and based on the determined indicators, the physico-chemical state of the analyzed rivers was determined.

Table 1 presents the average annual values of Jiu river physico-chemical quality indicators, oxygen and nutrient indicators, measured in three sampling sections: upstream confluence Sadu, downstream Tg. Jiu and Bilteni, between 2016 and 2018.

Table 1

INDICATORS OF THE OXYGEN REGIME AND THE NUTRIENT CONTENT OF JIU RIVER, MONITORING PERIOD 2016-2018

\begin{tabular}{|c|c|c|c|c|c|c|c|c|c|}
\hline \multirow{3}{*}{$\begin{array}{l}\text { Indicators } \\
\text { measured }\end{array}$} & \multicolumn{9}{|c|}{$\begin{array}{c}\text { Jiu river monitoring } \\
\text { RJ1- upstream Sadu confluence; RJ2- downstream Tg. Jiu; } \\
\text { RJ3 - Bilteni }\end{array}$} \\
\hline & \multicolumn{3}{|c|}{2016} & \multicolumn{3}{|c|}{2017} & \multicolumn{3}{|c|}{2018} \\
\hline & RJ1 & $\mathrm{RJ} 2$ & RJ3 & RJ1 & $\mathrm{RJ} 2$ & RJ3 & RJ1 & $\mathrm{RJ} 2$ & RJ3 \\
\hline $\begin{array}{c}\mathrm{DO} \\
\left(\mathrm{mg} \mathrm{O}_{2} / \mathrm{L}\right)\end{array}$ & 13.5 & 13.2 & 10.9 & 11.1 & 10.9 & 9.7 & 11.3 & 11.0 & 8.5 \\
\hline
\end{tabular}




\begin{tabular}{|c|c|c|c|c|c|c|c|c|c|}
\hline $\begin{array}{l}\text { COD-Cr } \\
\left(\mathrm{mg} \mathrm{O}_{2} / \mathrm{L}\right)\end{array}$ & 7.69 & 8.45 & 11.55 & 8.04 & 8.15 & 10.26 & 7.6 & 7.45 & 9.9 \\
\hline $\begin{array}{c}\mathrm{BOD}_{5} \\
\left(\mathrm{mg} \mathrm{O}_{2} / \mathrm{L}\right)\end{array}$ & 2.4 & 2.1 & 3.3 & 2.3 & 2.0 & 3.4 & 1.9 & 1.8 & 2.9 \\
\hline $\begin{array}{c}\mathrm{N}_{-\mathrm{NH}_{4}}{ }^{+} \\
(\mathrm{mg} \mathrm{N} / \mathrm{L})\end{array}$ & 0.034 & 0.1 & 0.22 & 0.085 & 0.07 & 0.08 & 0.04 & 0.03 & 0.05 \\
\hline $\begin{array}{c}\mathrm{N}^{-\mathrm{NO}_{2}}{ }^{-} \\
(\mathrm{mg} \mathrm{N} / \mathrm{L})\end{array}$ & 0.062 & 0.036 & 0.04 & 0.022 & 0.041 & 0.018 & 0.033 & 0.035 & 0.032 \\
\hline $\begin{array}{c}{\mathrm{N}-\mathrm{NO}_{3}}^{-} \\
(\mathrm{mg} \mathrm{N} / \mathrm{L})\end{array}$ & 0.98 & 0.95 & 0.97 & 0.72 & 0.81 & 0.75 & 0.62 & 0.65 & 0.81 \\
\hline $\begin{array}{c}\text { N-total } \\
(\mathrm{mg} \mathrm{N} / \mathrm{L})\end{array}$ & 1.29 & 1.39 & 1.48 & 0.91 & 1.19 & 1.024 & 0.75 & 1.02 & 1.00 \\
\hline $\begin{array}{l}\mathrm{P}-\mathrm{PO}_{4}^{3-} \\
(\mathrm{mg} \mathrm{P} / \mathrm{L})\end{array}$ & 0.065 & 0.055 & 0.061 & 0.035 & 0.064 & 0.09 & 0.055 & 0.079 & 0.052 \\
\hline $\begin{array}{c}\text { P-total } \\
\text { (mg P/L) }\end{array}$ & 0.074 & 0.065 & 0.072 & 0.044 & 0.07 & 0.1 & 0.059 & 0.082 & 0.059 \\
\hline
\end{tabular}

The graphical representation of the measured Jiu River indicators and the reporting to the maximum admissible values presented by Regulation 161/2006 are shown in Figures 1-4.

It has been observed that dissolved oxygen concentration varies depending on the current season, having the lowest values during winter. The average dissolved oxygen content is between 9.7-13.5 $\mathrm{mg} \mathrm{O}_{2} / \mathrm{L}$, leading to class I quality, for which the limit value of DO is $9 \mathrm{mg} \mathrm{O}_{2} / \mathrm{L}$, except for the average values corresponding to 2018 , in the RJ3 - Bilteni monitoring section, where the DO value corresponds to the grade a-II of quality (Fig.1). The explanation could be related to the diversification of specific industrial activities in the area that led to an increase in discharges of inefficient treated wastewater.

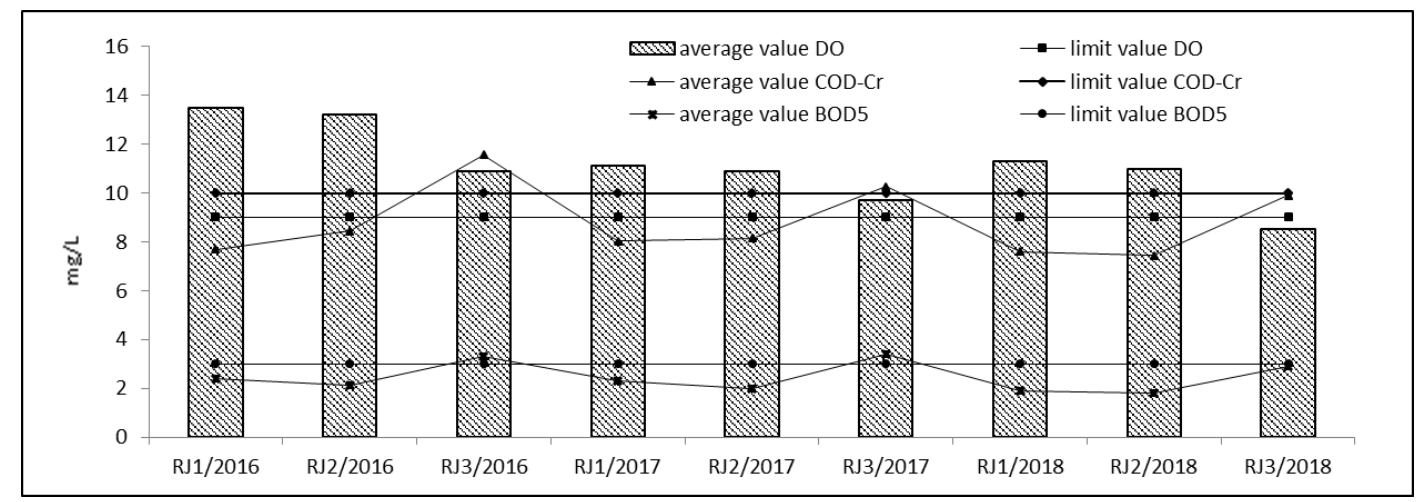

Fig. 1. Concentration values of DO, COD-Cr and $\mathrm{BOD}_{5}$ in Jiu River

For the chemical oxygen demand (COD-Cr) there were average annual values ranging from $7.45-11.55 \mathrm{mg}$ $\mathrm{O}_{2} / \mathrm{L}$ (Fig.1). For the RJ3 - Bilteni monitoring section, the average values corresponding to 2016 and 2017 exceed the limit value allowed by the 161/2006 Standard for Class Ia Quality (COD-Cr $=10 \mathrm{mg} \mathrm{O} / \mathrm{L}$ ), indicating pollution of the Jiu River with organic substances most likely due to insufficiently treated wastewater discharged into the emissary. Exceedings calculated on the basis of the Class I reference values are $1.02 \mathrm{LV}$ (limit value) for RJ3 in 2016 and 1.15 LV (limit value) for 2017.

As respects the variation of the biochemical oxygen demand at 5 days, in the RJ3 - Bilteni monitoring section, the average values corresponding to the years 2016 and 2017 are higher than the classification value allowed by the $161 / 2006$ Norm for Class Ia Quality (BOD5 $=3 \mathrm{mg} \mathrm{O}_{2} / \mathrm{L}$ ), so the water can be classified in the second quality class, which means that the evolution of this indicator and the source of the pollution must be continuously monitored (Fig.1).

The average nitrite content recorded for the Jiu River exceeds the limit value for Class I (LV=0.01 $\mathrm{mg}$ N/L) for all sections monitored. It can be seen that the recorded values are in the range of $4.1 \mathrm{LV}$ and $6.2 \mathrm{LV}$ for the nitrite content, the highest value corresponds to the section RJ1 (upstream confluence Sadu), in 2016 (Fig. 2). The ammonium content is within the limit value of Class I ( $\mathrm{LV}=0.4 \mathrm{mg} \mathrm{N} / \mathrm{L}$ ), ranging from 0.03 to $0.22 \mathrm{mg} \mathrm{N} / \mathrm{L}$ (Fig.2). 


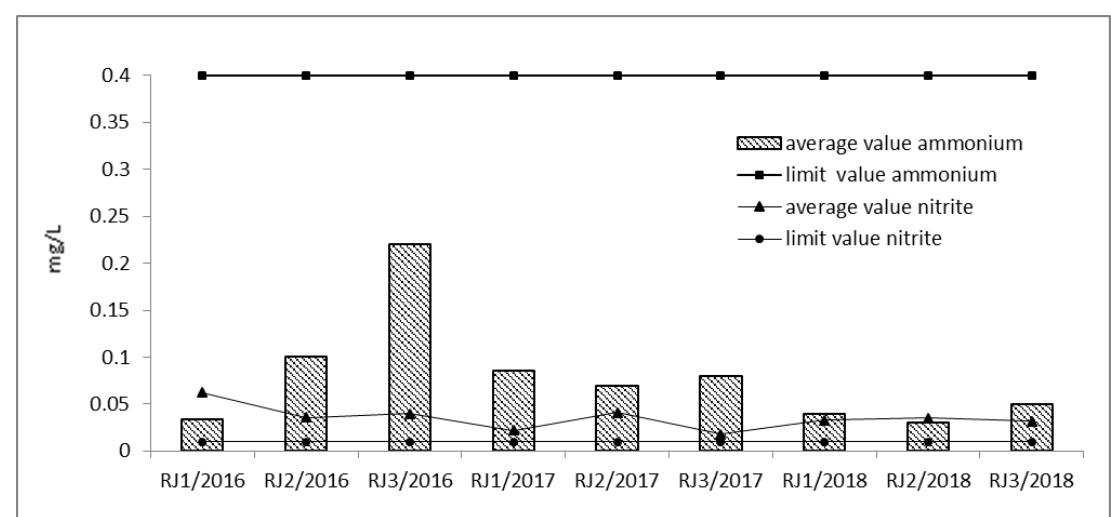

Fig 2. The variation of the average nitrite and ammonium concentration for the Jiu River

Regarding the concentration of nitrate, there is a variation within the range of $0.62-0.98 \mathrm{mg}$ N/L, with values very close to the limit value of quality class I ( $\mathrm{LV}=1 \mathrm{mg} \mathrm{N} / \mathrm{L}$ ), for all three monitored sections, during the year 2016 (Fig.3). The increased content of this year's concentration can be explained by either the lack of precipitation and, therefore the decrease in dilution, or by the occasional discharges of liquid waste of an organic nature. Thus, although in the view of this indicator the Jiu river water has been classified as quality I, permanent monitoring of this parameter is required. From the values recorded during the monitoring period, an evolution of $\mathrm{N}$-total content is observed below the admissible limit for quality class I and $1.5 \mathrm{mg} \mathrm{N} / \mathrm{L}$ (Fig.3).

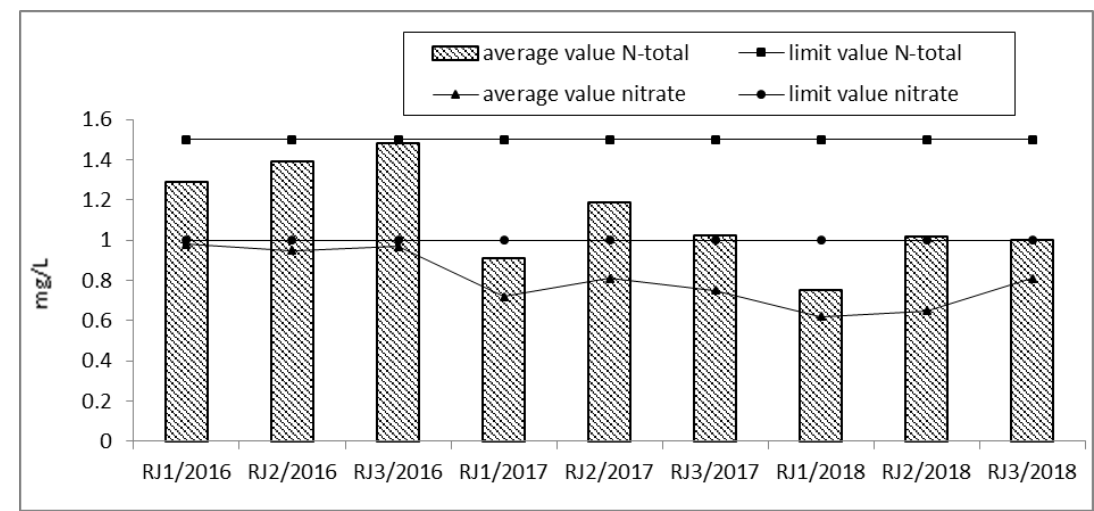

Fig 3. Variation of the average N-total and nitrate concentration for the Jiu River

Concerning phosphorus compounds, soluble orthophosphates were analyzed, for which the recorded values were within the range of $0.035-0.09 \mathrm{mg} \mathrm{P} / \mathrm{L}$ and total phosphorus having values ranging from $0.044-0.1 \mathrm{mg} / \mathrm{L}$ (Fig. 4), the maximum value for orthophosphates recorded in RJ3 in 2017 is very close to the limit value of $0.1 \mathrm{mg} P / \mathrm{L}$, which also requires monitoring of this indicator.

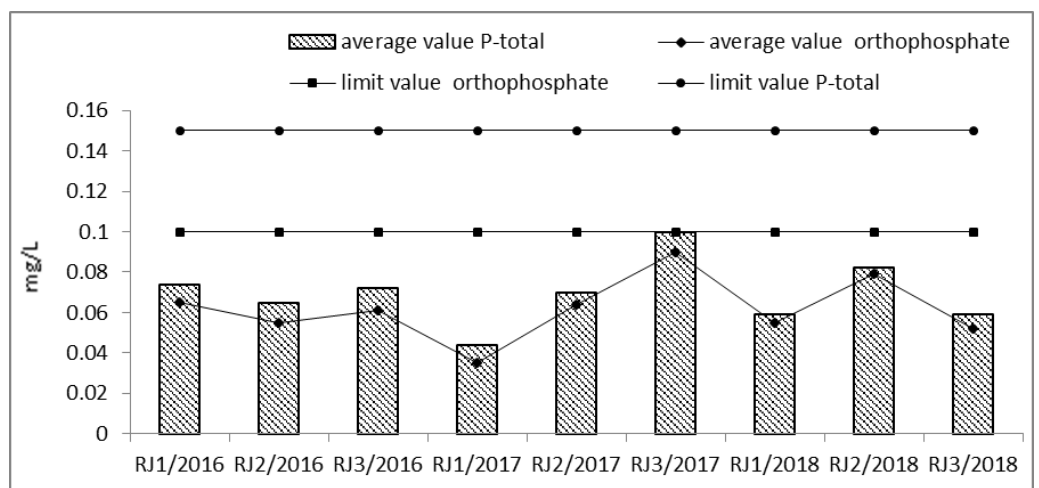

Fig. 4. Variation of orthophosphate and total P content indicators for the Jiu River

In Table 2 the average values of the oxygen and nutrient indicators of the Motru River are shown, a tributary of the Jiu river in the middle hydrographic basin, recorded during 2016-2018, in three sampling sections: upstream accumulation Valea Mare, accumulation Valea Mare dam, downstream accumulation Valea Mare. 
Table 2

INDEXES OF THE OXYGEN REGIME AND THE NUTRIENTS CONTENT FOR MOTRU RIVER, THE PERIOD OF MONITORING 2016-2018

\begin{tabular}{|c|c|c|c|c|c|c|c|c|c|}
\hline \multirow{3}{*}{$\begin{array}{l}\text { Measured } \\
\text { Indicators }\end{array}$} & \multicolumn{9}{|c|}{$\begin{array}{c}\text { Motru River monitoring } \\
\text { RM1- upstream accumulation Valea Mare; RM2- accumulation of the Valea Mare dam; RM3 - } \\
\text { downstream accumulation Valea Mare }\end{array}$} \\
\hline & \multicolumn{3}{|c|}{2016} & \multicolumn{3}{|c|}{2017} & \multicolumn{3}{|c|}{2018} \\
\hline & RM1 & RM2 & RM3 & RM1 & RM2 & RM3 & RM1 & RM2 & RM3 \\
\hline $\begin{array}{c}\mathrm{DO} \\
\left(\mathrm{mg} \mathrm{O}_{2} / \mathrm{L}\right)\end{array}$ & 13.3 & 13.2 & 13.1 & 12.5 & 11.9 & 12.4 & 8.7 & 8.7 & 10.8 \\
\hline $\begin{array}{c}\mathrm{COD}-\mathrm{Cr} \\
\left(\mathrm{mg} \mathrm{O}_{2} / \mathrm{L}\right)\end{array}$ & 6.5 & 4.15 & 5.71 & 5.92 & 5.62 & 6.51 & 5.92 & 5.65 & 4.53 \\
\hline $\begin{array}{c}\mathrm{BOD}_{5} \\
\left(\mathrm{mg} \mathrm{O}_{2} / \mathrm{L}\right)\end{array}$ & 1.3 & 1.3 & 1.5 & 1.1 & 1.2 & 1.3 & 1.5 & 1.3 & 1 \\
\hline 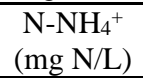 & 0.028 & 0.026 & 0.026 & 0.027 & $<0.025$ & 0.028 & $<0.025$ & 0.028 & $<0.025$ \\
\hline $\begin{array}{c}{\mathrm{N}-\mathrm{NO}_{2}{ }^{-}}(\mathrm{mg} \mathrm{N} / \mathrm{L})\end{array}$ & $<0.003$ & $<0.003$ & $<0.003$ & 0.004 & $<0.003$ & 0.004 & 0.03 & 0.02 & 0.01 \\
\hline $\begin{array}{c}\mathrm{N}^{-\mathrm{NO}_{3}}{ }^{-} \\
(\mathrm{mg} \mathrm{N} / \mathrm{L})\end{array}$ & 0.37 & 0.37 & 0.38 & 0.34 & 0.35 & 0.35 & 0.27 & 0.55 & 0.38 \\
\hline $\begin{array}{c}\text { N-total } \\
(\mathrm{mg} \mathrm{N} / \mathrm{L})\end{array}$ & 0.45 & $<0.5$ & 0.65 & $<0.5$ & 0.63 & $<0.5$ & $<0.5$ & 0.73 & $<0.5$ \\
\hline $\begin{array}{c}{\mathrm{P}-\mathrm{PO} 4^{3-}}(\mathrm{mg} \mathrm{P} / \mathrm{L}) \\
\end{array}$ & $<0.012$ & $<0.012$ & 0.014 & $<0.012$ & 0.016 & 0.015 & 0.019 & 0.022 & 0.017 \\
\hline $\begin{array}{c}\text { P-total } \\
\text { (mg P/L) }\end{array}$ & 0.008 & 0.009 & 0.009 & 0.011 & 0.015 & 0.014 & 0.021 & 0.036 & 0.011 \\
\hline
\end{tabular}

The charts corresponding to the evolution of the indicators monitored during the period 2016-2018 for the mentioned sections of the Motru River and the reference to the maximum values allowed by the Norm 161/2006 [24] are shown in Figures 5-8.

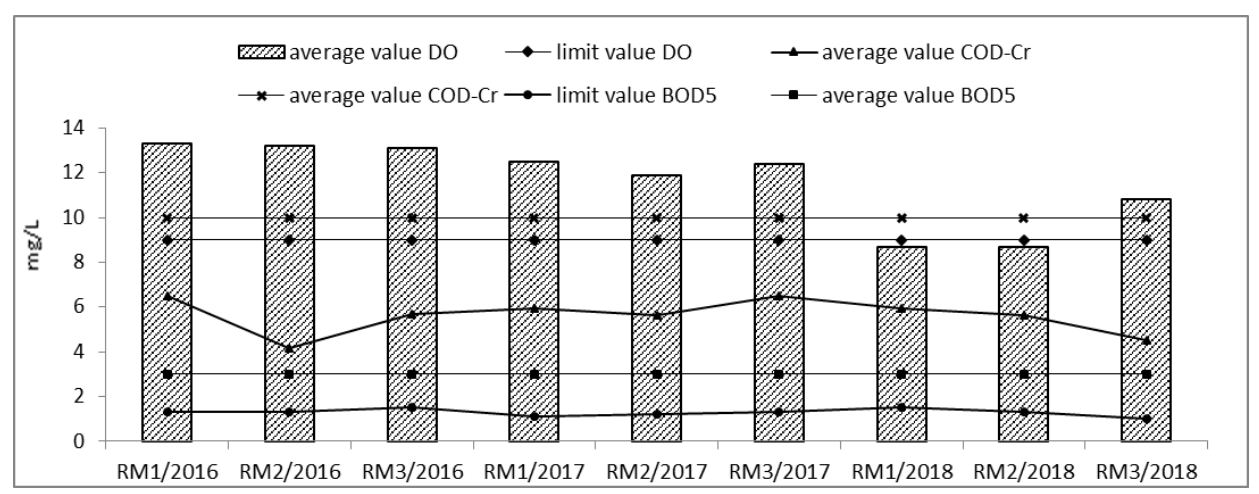

Fig. 5. Variation of DO, COD-Cr and $\mathrm{BOD}_{5}$ for the Motru River

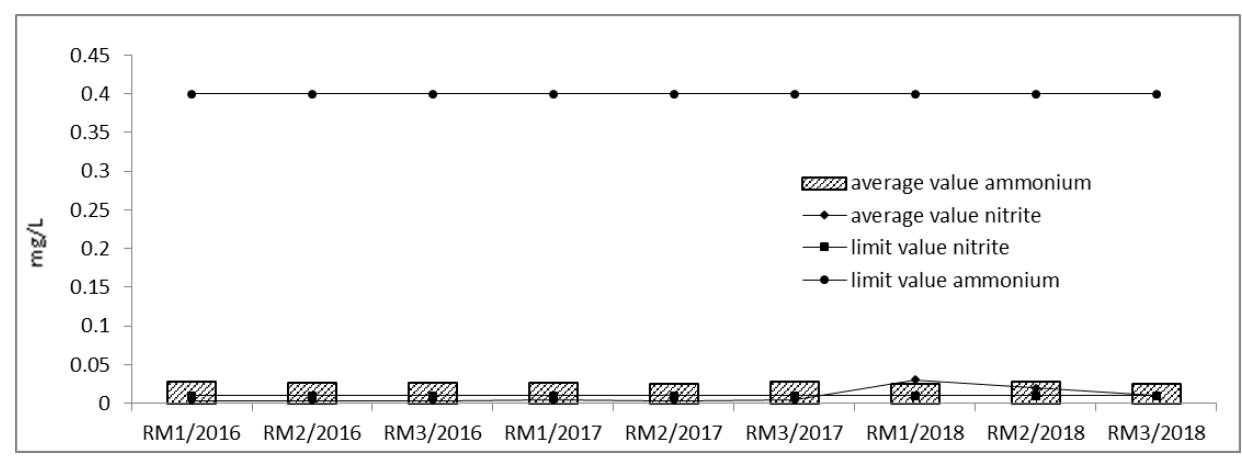

Fig. 6. Variation of ammonium and nitrite indicators for the Motru River 


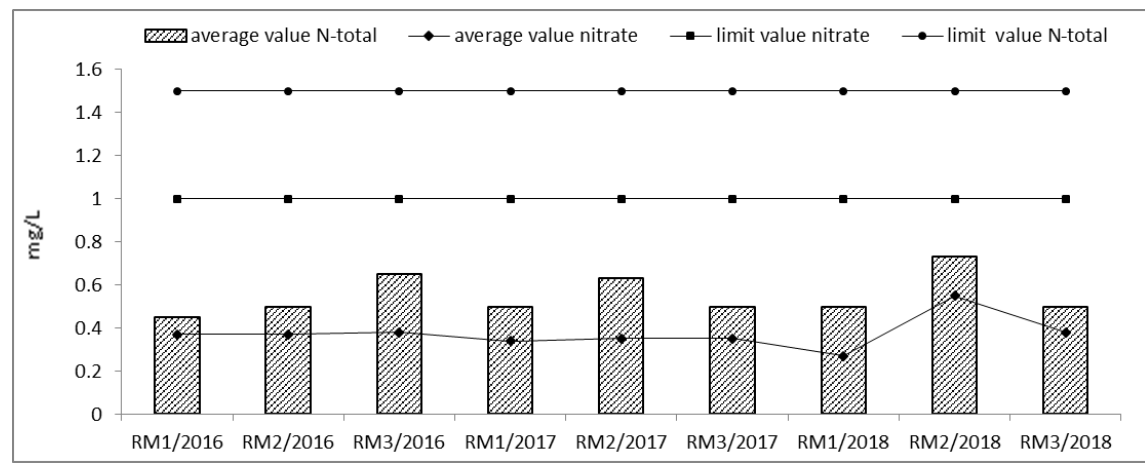

Fig 7. Variation of the $\mathrm{N}$-total and nitrate average concentration for the Motru River

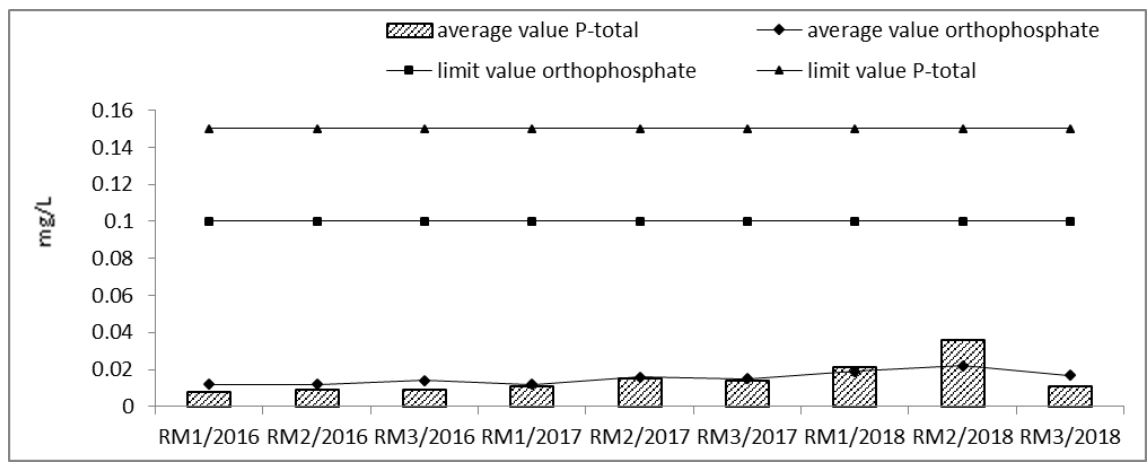

Fig. 8. Variation of orthophosphate and P-total indicators for the Motru River

The values of the measured indicators for the Motru River (Figure 5-8) and their linkage to the maximum permissible values indicate the following conclusions: the average dissolved oxygen content values are above the limit value of Class I of quality ranging from $8.7-13.3 \mathrm{mg} \mathrm{O}_{2} / \mathrm{L}$ (Figure 5). The other two COD-Cr and $\mathrm{BOD}_{5}$ indicators were within the limits of Class I quality (Figure 5).

For the monitored period, the average ammonium content was up to $0.028 \mathrm{mg} \mathrm{N} / \mathrm{L}$ (Figure6) and the nitrate content ranged from 0.27 to $0.55 \mathrm{mg} \mathrm{N} / \mathrm{L}$, the maximum value of the interval being recorded in the RM 2 section accumulation of Valea Mare dam in 2018 (Figure 7).

Regarding the nitrite content, an increase of the average values in 2018 for all three monitoring sections has been observed. The values corresponding to the RM1 section are about 10 times higher than in the previous years (Fig. 7). Thus, the average annual value reached the limit value admitted in the RM3 section in 2018 and exceeded, in sections RM1 and RM2, three or two times, the maximum allowed by the Norm 161/2006, for quality class I (LV $=0.01 \mathrm{mg} / \mathrm{L}$ ). For this period, the Motru River water has been classified in the second class of quality in terms of nitrite content, and therefore a permanent monitoring of this parameter is necessary.

The content of soluble orthophosphates also had an increasing tendency in 2018, but values were in the first grade of quality (Fig. 8). Similarly, for total phosphorus (Fig. 8), values ranging from $0.008-0.036 \mathrm{mg}$ P/L, below the limit value for class I $(\mathrm{LV}=0.15 \mathrm{mg} / \mathrm{L})$ were recorded.

Table 3 presents the average values of the oxygen and nutrient indicators of the Jilt River, affluent from the middle river basin of the Jiu River, monitored during 2016-2018, in two sampling sections: upstream of Bazavani and upstream of Turceni

The values of the physico-chemical indicators measured for the samples taken from the Jilt River were also reported to the maximum values allowed by the Norm 161/2006 for the first quality class and the graphical representation of their evolution is shown in figures $9-12$.

Table 3

OXIGEN REGIME AND NUTRIENTS CONTENT INDICATORS FOR JILT RIVER, MONITORING PERIOD $2016-2018$

\begin{tabular}{|c|c|c|c|c|c|c|}
\hline \multirow{3}{*}{$\begin{array}{l}\text { Measured } \\
\text { Indicators }\end{array}$} & \multicolumn{6}{|c|}{$\begin{array}{c}\text { Jilt River monitoring } \\
\text { Jt1- upstream Bazavani; Jt2- upstream Turceni }\end{array}$} \\
\hline & \multicolumn{2}{|c|}{2016} & \multicolumn{2}{|c|}{2017} & \multicolumn{2}{|c|}{2018} \\
\hline & $\mathrm{Jt} 1$ & $\mathrm{Jt} 2$ & $\mathrm{Jt} 1$ & $\mathrm{Jt} 2$ & Jt1 & $\mathrm{Jt} 2$ \\
\hline $\begin{array}{c}\mathrm{DO} \\
\left(\mathrm{mg} \mathrm{O}_{2} / \mathrm{L}\right)\end{array}$ & 13.5 & 11.8 & 12.5 & 11.2 & 9.9 & 9.4 \\
\hline
\end{tabular}




\begin{tabular}{|c|c|c|c|c|c|c|}
\hline $\begin{array}{c}\mathrm{COD}-\mathrm{Cr} \\
\left(\mathrm{mg} \mathrm{O}_{2} / \mathrm{L}\right)\end{array}$ & 9.53 & 10.33 & 8.45 & 11.32 & 9.83 & 13.11 \\
\hline $\begin{array}{c}\mathrm{BOD}_{5} \\
\left(\mathrm{mg} \mathrm{O}_{2} / \mathrm{L}\right)\end{array}$ & 2.5 & 2.7 & 2.6 & 3.1 & 3.3 & 3.6 \\
\hline $\begin{array}{c}\mathrm{N}-\mathrm{NH}_{4}{ }^{-} \\
(\mathrm{mg} \mathrm{N} / \mathrm{L})\end{array}$ & 0.015 & 0.13 & 0.056 & 0.066 & 0.08 & 0.095 \\
\hline $\begin{array}{c}\mathrm{N}-\mathrm{NO}_{2}{ }^{-} \\
(\mathrm{mg} \mathrm{N} / \mathrm{L})\end{array}$ & 0.052 & 0.04 & 0.03 & 0.083 & 0.015 & 0.047 \\
\hline $\begin{array}{c}\mathrm{N}-\mathrm{NO}_{3}{ }^{-} \\
(\mathrm{mg} \mathrm{N} / \mathrm{L})\end{array}$ & 0.94 & 0.86 & 0.65 & 0.93 & 0.18 & 0.44 \\
\hline $\begin{array}{c}\mathrm{N}-\mathrm{total} \\
(\mathrm{mg} \mathrm{N} / \mathrm{L})\end{array}$ & 1.35 & 1.26 & 0.93 & 1.17 & $<0.5$ & 0.79 \\
\hline $\begin{array}{c}\mathrm{P}-\mathrm{PO}{ }^{3-} \\
(\mathrm{mg} \mathrm{P} / \mathrm{L})\end{array}$ & 0.037 & 0.052 & 0.062 & 0.072 & 0.061 & 0.067 \\
\hline $\begin{array}{c}\mathrm{P}-\mathrm{total} \\
(\mathrm{mg} \mathrm{P} / \mathrm{L})\end{array}$ & 0.046 & 0.064 & 0.016 & 0.085 & 0.067 & 0.079 \\
\hline
\end{tabular}

It is noted that for the Jilt River, the average dissolved oxygen content is between $9.4-13.5 \mathrm{mg} \mathrm{O}_{2} / \mathrm{L}$ being higher than the limit value for quality class I for the entire monitoring period (Fig. 9).

Concerning COD-Cr, the average annual values were in the range of $8.45-13.11 \mathrm{mg} \mathrm{O}_{2} / \mathrm{L}$, with exceedings of the limit value for quality class $\mathrm{I}\left(\mathrm{LV}=10 \mathrm{mg} \mathrm{O}_{2} / \mathrm{L}\right.$ ). Exceedings recorded for the section Jt2 - upstream Turceni, in all three years of monitoring, were between $1.03 \mathrm{LV}-1.31 \mathrm{LV}$ and consequently the water can be included in quality II class (Fig. 9).

The average values for $\mathrm{BOD}_{5}$ stand between 2.5 and $3.6 \mathrm{mg} \mathrm{O} / \mathrm{L}$, with higher values in the years 2017-2018, where there is an increasing tendency in the evolution of this indicator (Fig. 9). Thus, according to the measurements in this period, the $\mathrm{BOD}_{5}$ value was above the admissible limit value $(\mathrm{LV}=3 \mathrm{mg} \mathrm{O} / \mathrm{L})$. Exceedings are in between the values of $1.02 \mathrm{LV}$ in section Jt2 (2017) and 1.2 LV in section Jt2 (2018).

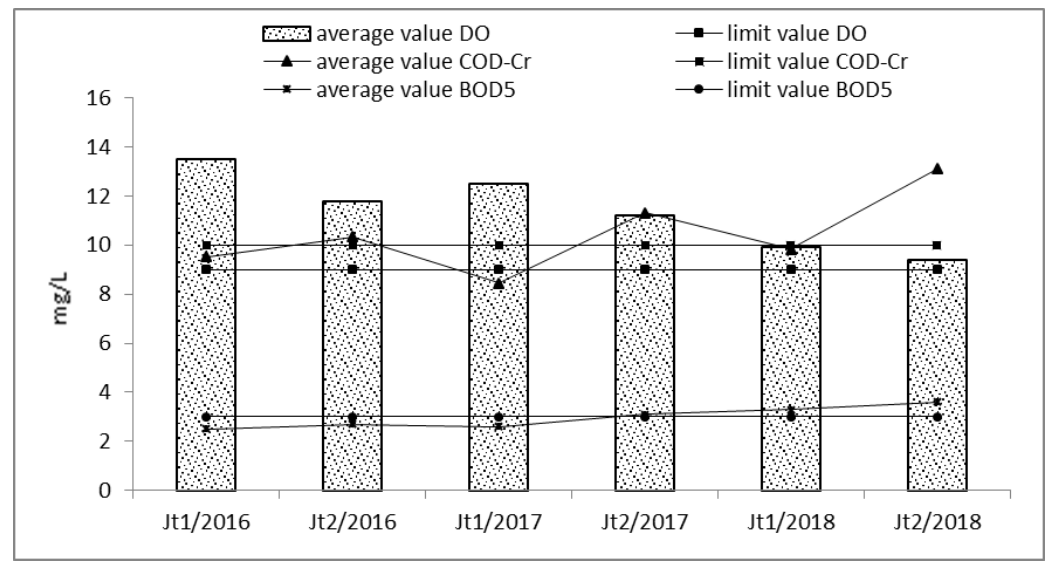

Fig. 9. Variation of DO, COD-Cr and BOD 5 for the Jilt River

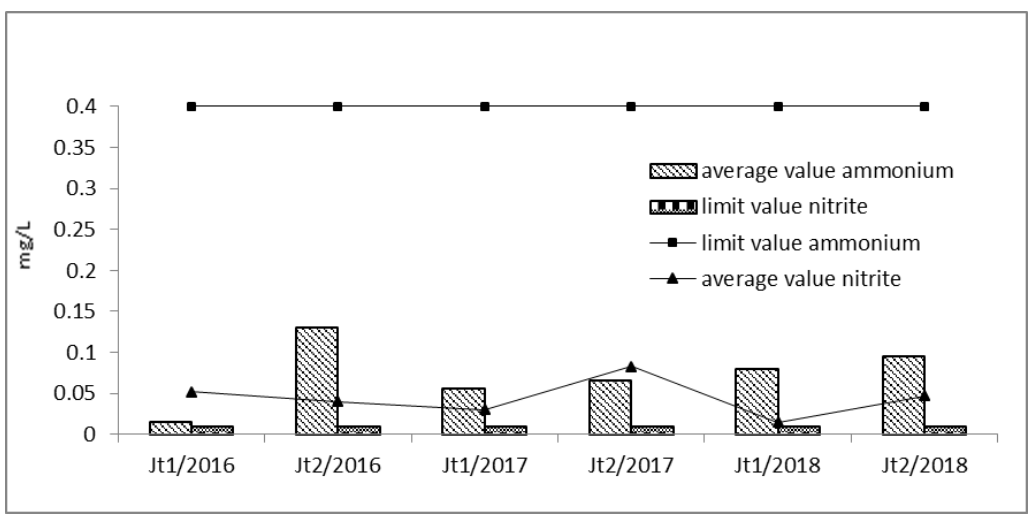

Fig. 10. Variation of ammonium and nitrite indicators for the Jilt River 


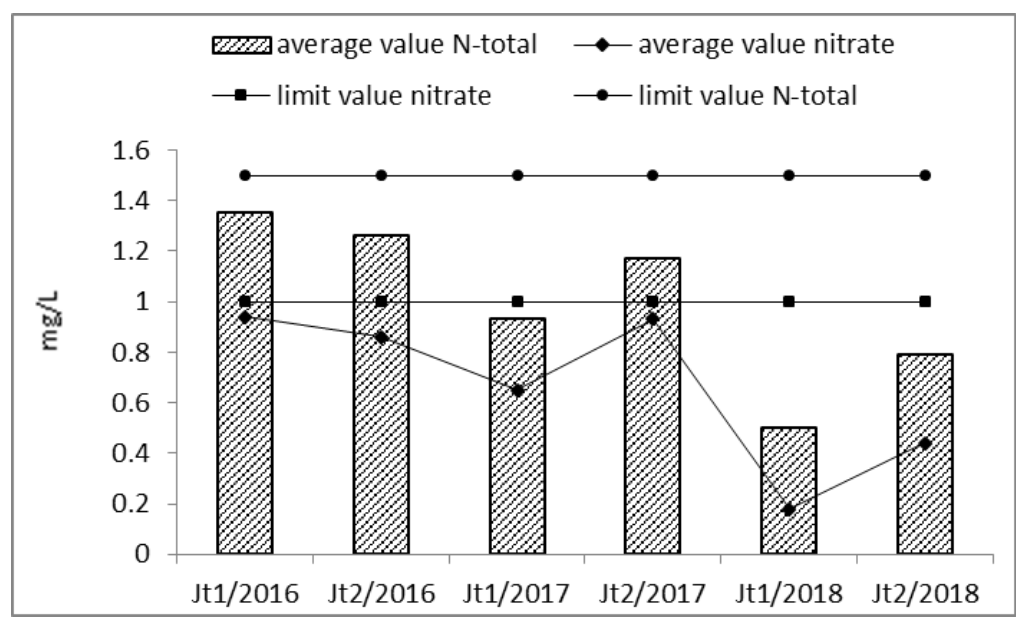

Fig. 11. Variation of N-total and nitrate indicators for the Jilt River

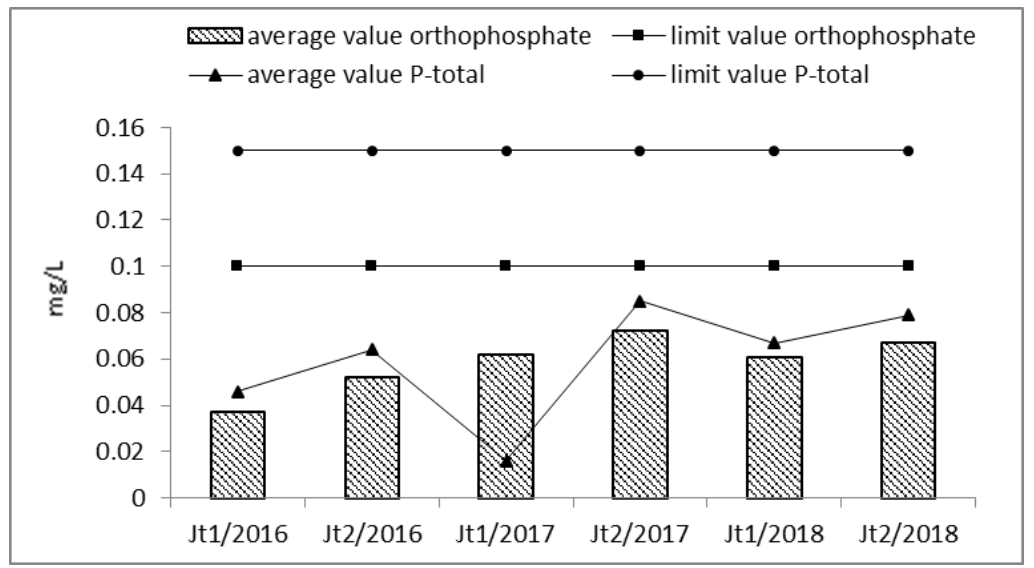

Fig. 12. Variation of orthophosphate and P-total indicators for the Jilt River

Regarding the nutrient regime of the Jilt River, it was evaluated with an ammonium content of between 0.015 and $0.095 \mathrm{mg} \mathrm{N} / \mathrm{L}$ (Figure 10). This value classifies water in Class I quality. Evolution of nitrite content values (Fig. 10) indicates that the limit value for quality class $\mathrm{I}(\mathrm{LV}=0.01 \mathrm{mg} \mathrm{N} / \mathrm{L})$ is exceeded for the two monitored sections during the period 2016-2018, the exceedings being in the range $1.5 \mathrm{LV}-8.3 \mathrm{LV}$, therefore the water is in Class II quality according to the Norm 161/2006 [24].

Higher levels of nitrite content indicate the presence of organic sources of pollution which lead to water, most likely due to industrial activities in the vicinity of the Jilt emissary. Consequently, continuous monitoring of this parameter that exceeds the upper limit of Class I water is recommended.

As for the variations in the average ammonium concentrations (Fig. 10), nitrate and total nitrogen (Figure 11) for the Jilt river, between 2016-2018, they have values below the maximum limit value corresponding to Class I quality for each of the mentioned indicators.

The soluble orthophosphate content ranged from $0.037-0.072 \mathrm{mg} \mathrm{P} / \mathrm{L}$ (Figure 12), with a maximum value close to the limit value of Class I quality $(\mathrm{LV}=0.1 \mathrm{mg} \mathrm{P} / \mathrm{L})$. The total phosphorus content, ranged between $0.016-0.085$ mg P L (Figure 12), includes the Jilt river water below the $0.15 \mathrm{mg} \mathrm{P} / \mathrm{L}$ limit value corresponding to Class I quality.

\section{Conclusions}

The purpose of this study was to track the evolution of the quality of water streams across the Gorj county by monitoring the oxygen and nutrient indicators, considering the vulnerability of surface waters to the action of anthropogenic sources of pollution. For the Jiu, Motru and Jilt rivers, 2016-2018, water quality monitoring was carried out by sampling from representative sections of the mentioned water courses and periodic analysis of the quality indicators: dissolved oxygen, chemical and biochemical oxygen demand, ammonium, nitrates, nitrites, total nitrogen, orthophosphates and total phosphorus. The values recorded during the monitoring period allowed the assessment of the quality of the water courses taken into study by reporting the values measured in the Norm 161/2006 and fitting into the corresponding quality class.

The analysis of recorded data for the Jiu River indicates its classification in the first quality class with respect to the monitored indicators, with the exception of the nitrites that exceeded the allowed limit value for all the monitored 
sections in the interval 2016-2018. There were also exceedances of the biochemical oxygen demand and of the chemical oxygen demand both in 2016 and in 2017 in one of the three monitored sections, indicating an average pollution level of the Jiu river with organic substances due to firstly insufficiently treated wastewater discharged into the emissary and permanent monitoring of the parameters that have exceeded. Also the dissolved oxygen content was below the limit value corresponding to Class I quality in one of the three sections monitored in 2018.

The monitoring of the Motru River was also carried out in three monitoring sections, for the period 2016-2018. All indicators were in the first quality class, with the exception of the nitrite content, for which there was an increase in the average values in 2018 of the previous years, values that exceeded, in two of the three sections, the maximum allowed by the Norm 161/2006 for the first quality class. Therefore, for the year 2018, the Motru River water was ranked second in quality class II in terms of nitrite content, and it was necessary to permanently monitor this parameter and identify the sources of pollution.

The average values of the physicochemical quality indicators of the Jilt river, a tributary of the Jiu river, monitored during 2016-2018, indicate an average dissolved oxygen content higher than the limit value for the first class of quality. Average values for $\mathrm{BOD}_{5}$ have an increase trend for the 2017-2018 period in the evolution of this indicator and exceeding the maximum admissible limit. In accordance with the measurements made for $\mathrm{BOD}_{5}$ in this period, the Jilt River was included in the 2nd quality class. Overdrivers recorded for the COD-Cr indicator in the Jt2 section upstream of Turceni, in all three years of monitoring, classifies water in quality class II.

Also, the evaluated nutrient regime indicates the existence of sources of organic matter-generating pollutants that most likely are discharged into the water as a result of the industrial activities in the area surrounding the emissary Jilt. There have been exceedings of the limit value of water quality class I for the nitrite indicator for the entire period, and it is recommended that this parameter to be continuously monitored for the Jilt river. The other indicators of the nutrient regime, nitrate, ammonium, total nitrogen, orthophosphate content and total $\mathrm{P}$ is below the limit value and classifies water in quality class I.

\section{References}

1. ARTEMIADOU, V., LAZARIDOU, M., Environmental monitoring assessment, 2005, p. 1-40.

2. VITAKU, A., BARUTI, B., MALOLLARI, I., SHALA, F., Journal of Environmental Protection and Ecology, Vol.14, No. 1, Thessaloniki Greece, 2013, p. 29-34.

3. CIRTINA, D., CAPATINA, C., SIMONESCU, C.M., Rev Chim., 66, no. 8, 2015, p. 1184.

4. HEINZ, I., PULIDO-VELAZQUEZ, M., LUND, JR., ANDREU, J. Water Resour Manag, 21, no. 7, 2007, p. 1103.

5. CIRTINA, D., PASARE, M., Rev Chim., 65, no. 6, 2014, p. 737.

6. LIU, J., LIU, Q., YANG, H., Ecological Indicators 60, 2016, p. 434.

7. CIRTINA, D., CAPATINA, C., Rev Chim., 67, no. 9, 2016, p. 1823.

8. HESSION, C., STRORM, D., Journal of Environmental Quality 29, 2000, p. 1172-1179.

9. CIRTINA, D., PASARE, M., CIRTINA, L.M, Rev Chim., 66, no. 7, 2015, p. 1057.

10. IORDACHE, M., MEGHEA, A., NEAMTU, S., POPESCU, L.R., IORDACHE, I., Rev. Chim., 65, no. 1, 2014 , p. 87.

11. BANU Z., CHOWDHURY MD. S. A., HOSSAIN MD. D., NAKAGAMI K., J. Water Resource Prot., 5, 2013, p. $239-248$.

12. CIRTINA, D., CAPATINA, C., Rev Chim., 68, no. 1, 2017, p. 72.

13. ROMANESCU, G., TARNOVAN, A., SANDU, I.G., COJOC, G.M., DASCALITA, D., SANDU, I., Rev. Chim., 65, no. 10, 2014 , p. 1168.

14. ARDUINO, G., REGGIANI, P., TODINI, E., Hydrol. Earth Syst. Sc., 9, no. 4, 2005, p. 280.

15. DUMITRACHE, F., DIACU, E., Rev. Chim., 61, no. 3, 2010, p. 328.

16. ROMANESCU, G., HAPCIUC, O.E., SANDU, I., MINEA, I., DASCALITA, D., IOSUB, M., Rev. Chim., 67, no. 2, 2016 , p. 245.

17. BADALUTA-MINDA, C., CRETU, G., Environ. Eng. Manag. J., 9, no. 4, 2010, p. 535.

18. BARBULESCU, A., BARBES, L., Rev. Chim., 64, no. 8, 2013, p. 868.

19. RADU, V.M., IVANOV, A.A., IONESCU, P., GYORGY, D., DIACU, E., Rev. Chim., 67, no. 3, 2016, p. 391.

20. CIRTINA, D., CAPATINA, C., SIMONESCU C.M., Rev. Chim., 67, no. 3, 2016, p. 538.

21. CAPATINA, C., GAMANECI GH., SIMONESCU C.M., Journal of Environmental Protection and Ecology, 13, no. 3, 2012 , p.1375.

22. CAPATINA, C., SIMONESCU C.M., Environmental Engineering and Management Journal, 7, no. 6, 2009, p. 717.

23. *** SR ISO 5667-6:1997. Water Quality. Sampling. Guide for sampling of rivers and watercourses.

24.*** MESDR, Order of Ministry (Ministry of Environment and Sustainable Development of Romania) no. 161/2006, for the approval of the Norms regarding the classification of surface water quality in order to establish the ecological status of the water body

Manuscript received: 13.06 .2019 